\title{
RESEARCA STS \\ PHYSICAL ACI \\ No effect of acute or chronic bovine colostrum supplementation on circulating insulin-like growth factor-I
}

Autor(es): $\quad$ Jones, Arwel W; Davison, Glen

Publicado por: Imprensa da Universidade de Coimbra

URL persistente:

URI:http://hdl.handle.net/10316.2/44150

DOI:

DOI:https://doi.org/10.14195/2182-7087_ex2018_87

Accessed : $\quad$ 26-Apr-2023 12:18:12

A navegação consulta e descarregamento dos títulos inseridos nas Bibliotecas Digitais UC Digitalis, UC Pombalina e UC Impactum, pressupõem a aceitação plena e sem reservas dos Termos e Condições de Uso destas Bibliotecas Digitais, disponíveis em https://digitalis.uc.pt/pt-pt/termos.

Conforme exposto nos referidos Termos e Condições de Uso, o descarregamento de títulos de acesso restrito requer uma licença válida de autorização devendo o utilizador aceder ao(s) documento(s) a partir de um endereço de IP da instituição detentora da supramencionada licença.

Ao utilizador é apenas permitido o descarregamento para uso pessoal, pelo que o emprego do(s) título(s) descarregado(s) para outro fim, designadamente comercial, carece de autorização do respetivo autor ou editor da obra.

Na medida em que todas as obras da UC Digitalis se encontram protegidas pelo Código do Direito de Autor e Direitos Conexos e demais legislação aplicável, toda a cópia, parcial ou total, deste documento, nos casos em que é legalmente admitida, deverá conter ou fazer-se acompanhar por este aviso. 


\section{ANNALS OF RESEARCH IN SPORT AND PHYSICAL ACTIVITY}




\title{
NO EFFECT OF ACUTE OR CHRONIC BOVINE COLOSTRUM SUPPLEMENTATION ON CIRCULATING INSULIN-LIKE GROWTH FACTOR-I
}

\author{
Arwel W Jones ${ }^{1}$; Glen Davison²
}

\section{INTRODUCTION}

The World Anti-Doping Agency does not recommend the consumption of bovine colostrum (COL) as it contains prohibited substances (e.g. insulin-like growth factor-I, IGF-I) that may influence the outcome of anti-doping tests. Our aim was to perform post-hoc analysis of samples collected in three prospective, placebo-controlled randomised trials of COL supplementation and immune health from our laboratory.

\section{METHODS}

IGF-I concentration was quantified in duplicate pre-treated (to release IGF-I from binding proteins) plasma samples via an enzyme-linked immunosorbent assay. Eighty nine healthy, recreationally active males were included from published (Study 1: Jones et al., 2014, Study 2: Jones et al., 2015) and yet to be published investigations of COL supplementation. We also determined IGF-I concentrations in COL and placebo (PLA) (isoenergetic/isomacronutrient mixture of skimmed milk powder and milk protein concentrate) supplements and commercially available milk products.

\section{RESULTS}

COL supplement $(70 \mathrm{ng} / \mathrm{ml}$ ) contained an approximate eight-fold greater level of IGF-I than PLA (8 ng/ml), whole milk $(9 \mathrm{ng} / \mathrm{ml})$, semi-skimmed milk $(9 \mathrm{ng} / \mathrm{ml})$ and skimmed milk

\footnotetext{
1 Lincoln Institute for Health, University of Lincoln.

2 School of Sport and Exercise Sciences, University of Kent, UK.

Email: arjones@lincoln.ac.uk; arwelwjones@live.co.uk
} 
(9 ng/ml). In study 1, compared to placebo ( $\mathrm{n}=28$, baseline: $107 \pm 38 \mathrm{ng} / \mathrm{ml}, 12$ weeks: $104 \pm 37 \mathrm{ng} / \mathrm{ml})$, 12 weeks of COL (20 g per day) supplementation ( $n=25$, baseline: $96 \pm$ $26 \mathrm{ng} / \mathrm{ml}$, 12 weeks: $93 \pm 24 \mathrm{ng} / \mathrm{ml}$ ) did not lead to changes in circulating IGF-I (two-factor mixed ANOVA, group: $p=0.400$, group $x$ time interaction: $p=0.498$, time $p=0.602$ ). In study 2, there were no differences in circulating IGF-I between PLA $(n=10$, baseline: $109 \pm$ $27 \mathrm{ng} / \mathrm{ml}$, 4 weeks: $119 \pm 35 \mathrm{ng} / \mathrm{ml})$ and COL $(\mathrm{n}=10$, baseline: $107 \pm 21 \mathrm{ng} / \mathrm{ml}, 4$ weeks: $106 \pm 21 \mathrm{ng} / \mathrm{ml}$ ) groups following 4 weeks of ( $20 \mathrm{~g}$ per day) supplementation (two-way mixed ANOVA, group: $p=0.584$, group $x$ time interaction: $p=0.083$, time $p=0.243$ ). In study 3, two-factor repeated measures ANOVA (group: $p=0.133$, group $x$ time interaction: $p=0.166$, time $p=0.013$ ) revealed a change over time but not any significant differences in IGF-1 between a total acute dose of $40 \mathrm{~g}$ of COL $(n=16$, baseline: $130 \pm 36 \mathrm{ng} / \mathrm{ml}, 1$ hour: $132 \pm 34 \mathrm{ng} / \mathrm{ml}, 5$ hours: $126 \pm 32 \mathrm{ng} / \mathrm{ml}$ ) or PLA ( $n=16$, baseline: $133 \pm 39 \mathrm{ng} / \mathrm{ml}, 1$ hour: $141 \pm 39 \mathrm{ng} / \mathrm{ml}, 5$ hours: $133 \pm 39 \mathrm{ng} / \mathrm{mll}$.

\section{CONCLUSION}

Despite greater concentration of IGF-I in COL products compared to energy matched PLA supplements and commercially available milk products, these findings provide further evidence that acute and chronic COL consumption do not change circulating levels of IGF-1.

\section{REFERENCES}

1. Jones AW, Cameron SJ, Thatcher R, Beecroft MS, Mur LA, Davison, G. (2014). Effects of bovine colostrum supplementation on upper respiratory illness in active males. Brain Behav Immun, 39, 194-203.

2. Jones AW, Thatcher R, March DS, Davison G. (2015). Influence of 4 weeks of bovine colostrum supplementation on neutrophil and mucosal immune responses to prolonged cycling. Scand J Med Sci Sports, 25, 788-796. 